\title{
Efektivitas Aromaterapi Lemon untuk Mengatasi Emesis Gravidarum
}

\author{
Siti Rofi'ah ${ }^{1}$ Sri Widatiningsih ${ }^{2}$ Tuti Sukini ${ }^{3}$ \\ 1,2,3 Prodi Kebidanan Magelang Poltekkes Kemenkes Semarang \\ Corresponding author: Siti Rofi'ah \\ Email: nandasheeta@yahoo.com
}

Received: December $20^{\text {th }}, 2018$; Revised: January $18^{\text {th }}, 2019 ;$ Accepted: February $13^{\text {th }}, 2019$

\begin{abstract}
Symptoms that often arise in the early months of pregnancy are nausea followed by vomiting (emesis). The content of Linalil in lemon aromatherapy is useful for normalizing the emotional state and unbalanced state of the body and functions as a sedative. The pungent odor caused by geranil acetate can stimulate the release of hormones that can calm and cause feelings of calm and affect the physical and mental changes of pregnant women so that complaints of nausea and vomiting are reduced.The aim of the study was to determine the effectiveness of lemon aromatherapy in overcoming the emesis of gravidarum. This type of research is quasy-experimental, in the form of Pretest-Postest with Control Group Design. Retrieval of research data using a closed questionnaire with Rhodes Index of Nausea Vomiting and Retching (INVR). Sampling with a total sampling of 46 patients was divided into 3 groups, namely $0.1 \mathrm{ml}$ / $0.2 \mathrm{ml} / 0.3 \mathrm{ml}$ aromatherapy intervention. Processing data using ANOVA test.The results of the study state that there is no difference in the effectiveness of each dose of lemon aromatherapy in overcoming the emesis of gravidarum. Descriptively, there was a difference in changes in the score of nausea and vomiting in each dose group, namely $7 ; 17 ; 20$.The results of this study are expected to be used as input for the Head of the Health Office in establishing policies on herbal medicine as a substitute for pharmacological drugs so that midwives can use alternative therapies to overcome complaints of nausea and vomiting in pregnant women. For companies herbal medicine can be used as a discourse to create herbal products, especially lemon aromatherapy with varied doses and affordable prices as a therapy to treat nausea and vomiting in pregnant women
\end{abstract}

Keyword: lemon aromatherapy; emesis gravidarum

\section{Pendahuluan}

Tingginya angka kekurangan gizi pada ibu hamil cukup memberikan kontribusi terhadap tingginya angka Berat Badan lahir Rendah (BBLR) di Indonesia (Direktorat Jenderal Bina Gizi dan KIA Kemenkes RI, 2011). Salah satu faktor yang dapat mempengaruhi status gizi pada ibu hamil adalah keluhan mual dan muntah (emesis gravidarum) terutama pada awal kehamilan. Mual dan muntah merupakan gejala paling awal, paling umum dan dapat menyebabkan beban psikologis bagi ibu hamil yang terkait dengan kehamilannya. Mual muntah dalam kehamilan diakibatkan peningkatan hormon estrogen dan Human Chorionik Gonadrotropin (HCG) yang jika tidak segera ditangani akan berlanjut pada hyperemesis gravidarum(Tiran, 2009).

Mual dan muntah yang terus menerus dapat menyebabkan cairan tubuh berkurang, sehingga darah menjadi kental (hemokonsentrasi) dan sirkulasi darah ke jaringan terlambat. Hal ini akan menyebabkan kerusakan jaringan yang dapat mengganggu kesehatan ibu dan perkembangan janin. Penanganan mual muntah tergantung pada tingkat keparahan gejala yang dirasakan. Pengobatan dapat menggunakan terapi farmakologis maupun non farmakologis. Terapi farmakologis dapat dilakukan dengan pemberian antiemetik, antihistamin, antikolinergik dan kortikosteroid. Sedangkan terapi non farmakologis dapat dilakukan dengan pengaturan diet, dukungan emosional, akupunktur, perubahan pola hidup, istirahat, tidur dan dengan pemberian pengobatan herbal/ alamiah seperti jahe maupun peppermint (Runiari, 2010)(Tiran, 2009).

Penanganan emesis gravidarum menurut(Rinata and Ardillah, 2015)dengan menggunakan terapi farmakologis sudah tepat namun sebagian besar belum tepat dalam 
melakukan pengobatan herbal/ alamiah. Pada penelitian sebelumnya, peneliti memperoleh hasil bahwa dari 8 orang ibu hamil yang mengalami hiperemesis gravidarum, hanya satu orang yang mengkombinasikan terapi farmakologis dengan non farmakologis. Sebagian besar hanya mengandalkan obat-obatan yang diberikan tenaga kesehatan dalam mengatasi keluhan mual muntah(Rofi'ah, Widatiningsih and Sukini, 2017).

Salah satu alternatif untuk mengatasi mual muntah dalam kehamilan secara non farmakologis adalah dengan menggunakan aromaterapi. Beberapa jenis minyak essensial dapat digunakan sebagai aromaterapi, antara lain peppermint, spearmint, lemon dan jahe. Hasil penelitian (Santi, 2013)menyatakan bahwa ada pengaruh aromaterapi blended pepermint dan ginger oil terhadap rasa mual pada ibu hamil trimester I di Puskesmas Rengel Kabupaten Tuban. Aromaterapi blended peppermint dan ginger oil merupakan salah satu cara mudah, sederhana, efektif dan tanpa efek samping yang dapat digunakan untuk mengurangi keluhan ibu hamil karena memberikan berbagai efek antara lain ketenangan, kesegaran, bahkan dapat membantu ibu hamil mengatasi mual.

Kandungan minyak atsiri Zingiberena (zingirona), zingiberol, bisabilena, kurkumen, gingerol, flandrena, vit A dan resin pahit pada jahe dapat memberikan rasa nyaman dalam perut sehingga dapat mengatasi mual muntah (Ahmad, 2013). Lavender juga merupakan salah satu jenis aromaterapi karena memiliki zat aktif berupa linalool dan linalyl acetate yang dapat berefek sebagai analgesik (Wolfgang and Michaela, 2008).

Aromaterapi lemon adalah minyak essensial yang dihasilkan dari ekstrak kulit jeruk (Citrus Lemon) yang sering digunakan dalam aromaterapi. Aromaterapi lemon adalah jenis aromaterapi yang aman untuk kehamilan dan melahirkan(Medforth et al., 2013). Meskipun mahal, minyak essensial Lemon merupakan salah satu minyak herbal yang paling banyak digunakan dan aman bagi kehamilan. Menurut studi, $40 \%$ wanita telah menggunakan aroma lemon dalam meredakan keluhan mual dan muntah. Dari sekian tersebut 26,5 \% melaporkan bahwa aroma lemon merupakan cara yang efektif untuk mengontrol gejala mual muntah(Kia et al., 2014).

Pada Lemon terkandung Limonene yang akan menghambat kerja prostaglandin sehingga dapat mengurangi rasa nyeri serta berfungsi untuk mengontrol sikooksigenase I dan II, mencegah aktivitas prostaglandin dan engurangi rasa sakit termasuk mual muntah (Cheraghi and Valadi,
2010)(Namazi et al., 2014). Kandungan Linalil Asetat pada aromaterapi lemon berfungsi untuk menormalkan keadaan emosi serta keadaan tubuh yang tidak seimbang serta memiliki khasiat sebagai penenang dan tonikum khususnya pada sistem syaraf (Wiryodigdo, 2008). Berdasarkan hal tersebut, peneliti ingin mengetahui lebih lanjut tentang "Efektivitas Aromaterapi Lemon dalam Mengatasi Emesis Gravidarum"

\section{Metode Penelitian}

Desain penelitian ini adalah studi quasyexperimental design, dengan bentuk PretestPostestwith Control Group Design.Populasi penelitian ini adalah semua ibu hamil trimester I di wilayah kerja Puskesmas Mungkid Kabupaten Magelang pada bulan September-Oktober 2018. Berdasarkan data Puskesmas Mungkid K1 ibu hamil pada bulan September sebanyak 55 orang. Teknik sampling menggunakan total sampling. Sampel diambil berdasarkan kriteria inklusi yaitu ibu hamil yang mengalami mual muntah, keadaan umum ibu baik, tidak mengalami penyakit yang berhubungan dengangastrointestinal seperti thypoid, gastritis, tidak mengalami stress/ beban psikologi lain, tidak alergi terhadap bau aromaterapi lemon. Kriteria eksklusinya adalah menggunakan intervensi lain untuk mengatasi mual muntah, tidak melakukan pemberian aromaterapi selama 12 jam/ gugur. Berdasarkan kriteria tersebut diperoleh 467 orang sampel.

Pengumpulan data diawali dengan enumerator menanyakan kuesioner untuk mengukur derajat mual muntah sebelum diberikan perlakuan dan mengisikan jawaban responden pada lembar kuesioner. Selanjutnya menentukan kandungan aromaterapi lemon yang tepat sesuai keinginan/ kepekaan ibu terhadap rangsangan bau aromaterapi dengan cara mencoba membau jenis aromaterapi $\quad 0,1 \mathrm{ml} / \quad 0,2 \mathrm{ml} / \quad 0,3 \quad \mathrm{ml}$ dan memberikan jenis aromaterapi yang tepat dan menjelaskan cara melakukan intervensi yaitu dengan menghirup tisu pada saat mengalami mual dan atau muntah selama 5 menit yang sudah diberikan \pm 5 tetes minyak essensial lemon selama 12 jam yang dilanjutnya menanyakan derajat mual muntah setelah dilakukan intervensi.Alat ukur dalam penelitian ini adalah RHODES berdasarkan skor yang diperoleh atas jawaban responden tentang kejadian mual muntah yang dialami. Analisa bivariat penelitian ini menggunakan uji statistik ANOVA. 


\section{Hasil dan Pembahasan}

Analisa hasil penelitian menunjukkan terdapat perubahan rata-rata skor mual muntah pada ibu hamil pada masing-masing dosis seperti yang tercantum pada tabel 1 .

Tabel 1

Distribusi Frekuensi Derajat Emesis Gravidarum

\begin{tabular}{llccccc}
\hline Groups & $\begin{array}{c}\text { Rhodes } \\
\text { Score }\end{array}$ & $\begin{array}{c}\text { Mea } \\
\text { n }\end{array}$ & $\begin{array}{c}\text { Mea } \\
\text { niff. }\end{array}$ & $\begin{array}{c}\text { SD } \\
\text { Ma } \\
\text { Ma } \\
\mathbf{x}\end{array}$ & $\begin{array}{c}\mathbf{P} \\
\text { value } \\
\text { Uji t }\end{array}$ \\
\hline Dosis & Before & 8.41 & 3.12 & .95 & $3-19$ & .051 \\
0.1 & After & 5.29 & & .83 & $0-19$ & \\
$(\mathrm{n}=17)$ & & & & & & \\
\hline Dosis & Before & 11.4 & 5.34 & .36 & $4-21$ & .001 \\
0.2 & After & 7 & & .84 & $0-14$ & \\
$(\mathrm{n}=15)$ & & 6.13 & & & & \\
\hline $\begin{array}{l}\text { Dosis } \\
0.3\end{array}$ & Before & 11.5 & 7.79 & .38 & $4-23$ & .002 \\
$(\mathrm{n}=14)$ & After & 0 & & .20 & $0-9$ & \\
\hline
\end{tabular}

Hasil Analisa menggunakan uji Anova menunjukkan bahwa tidak ada perbedaan efektivitas masing-masing dosis aromaterapi lemon dalam mengatasi emesis gravidarum. Hal ini dapat dilihat pada tabel 2. sebagai berikut:

Tabel 2

Distribusi Frekuensi Perubahan Derajat EmesisGravidarum

\begin{tabular}{|c|c|c|c|c|c|c|}
\hline Groups & Mean & SD & $\begin{array}{l}\text { Min- } \\
\text { Max }\end{array}$ & Range & $\begin{array}{l}\text { P value* } \\
\text { Homogenity } \\
\text { of Varian }\end{array}$ & $\begin{array}{c}\text { P } \\
\text { value* } \\
\text { ANOVA }\end{array}$ \\
\hline $\begin{array}{c}\text { Dosis } \\
0.1 \\
(\mathrm{n}=17)\end{array}$ & 3.12 & 6.09 & $\begin{array}{c}(-11) \\
-18\end{array}$ & 7 & 0.127 & 0.127 \\
\hline $\begin{array}{c}\text { Dosis } \\
0.2 \\
(\mathrm{n}=15) \\
\end{array}$ & 5.33 & 4.73 & $0-17$ & 17 & & \\
\hline $\begin{array}{c}\text { Dosis } \\
0.3 \\
(n=14)\end{array}$ & 7.79 & 7.63 & $\begin{array}{c}(-1)- \\
21\end{array}$ & 20 & & \\
\hline
\end{tabular}

Tingkat emesis gravidarum sebelum diberikan aromaterapi lemon

Emesis gravidarum adalah gejala yang wajar atau sering terdapat pada kehamilan trimester pertama (Wiknjosastro, 2007). Kejadian ini biasanya dimulai antara minggu keempat dan ketujuh kehamilan, puncak di sekitar minggu kesembilan dan berakhir pada minggu ke-20 pada 90\% wanita ('The Management of Nausea and
Vomitting of Pregnancy and Hyperemesis Gravidarum', 2016). Bentuk mual dan muntah selama kehamilan dapat berupa gejala ringan yang khas, sedang, yang dapat sembuh dengan sendirinya dengan atau tanpa disertai muntah hingga kondisi berat yaitu hiperemesis gravidarum yang dapat menyebabkan penurunan berat badan, gangguan elektrolit dan metabolik serta kemungkinan jangka panjang (Tiran, 2009).

Penilaian tingkat emesis dapat dilakukan dengan menggunakan teori Rhodes seperti yang dilakukan pada penelitian (Apriany, 2010). Pada awalnya Indeks Rhodes digunakan untuk mengukur gejala mual muntah pada pasien kemoterapi termasuk penilaian gejala fisik dan stres yang ditimbulkan, tetapi dalam perkembangannya kemudian digunakan untuk mengukur derajat mual muntah pada emesis gravidarum('The Management of Nausea and Vomitting of Pregnancy and Hyperemesis Gravidarum', 2016).

Tingkat emesis gravidarum pada masingmasing ibu hamil berbeda-beda. Pada penelitian ini sebelum diberikan intervensi aromaterapi lemon diperoleh hasil rentang skor $0-23$. Seperti halnya penelitian (Kundarti, Rahayu and Utami, 2015) yang menyebutkan bahwa sebelum dilaksanakan penelitian, tingkat mual muntah berada pada kelompok ringan, sedang dan berat. Pada penelitian tersebut disarankan agar dalam mengatasi mual muntah terlebih dahulu dengan cara yang alami yaitu menghindari faktor pemicu dengan tidak makan makanan berlemak dan berbumbu. Kebutuhan nutrisi ibu juga harus lebih diperhatikan dengan mengkonsumsi makanan sedikit-sedikit tetapi sering untuk menghindari perut kosong dan membantu proses metabolisme karbohidrat lebih baik.

Sejumlah responden sebelum diberikan aromaterapi lemon memiliki skor Rhodes diatas rata-rata. Pada masing-masing dosis $0.1 ; 0.2$; dan 0.3 terhitung ada $35.3 \% ; 40 \%$ dan $43 \%$. Beberapa penelitian menyebutkan bahwa emesis gravidarum disebabkan faktor psikologis seperti kehamilan yang tidak diinginkan, perasaan marah, bersalah, cemas dan ketakutan yang akan menambah keparahan mual muntah(Niebyl and Briggs, 2014). Oleh sebab itu, derajat keparahan mual muntah pada masing-masing ibu hamil bervariatif dari mulai mual ringan hingga muntah berlebihan sehingga termasuk kategori hiperemesis gravidarum. Emesis gravidarum dapat menimbulkan gangguan aktivitas sehari-hari, bahkan bisa membahayakan bagi ibu dan janin (Munjiah et al., 2015). 
Emesis gravidarum yang bertambah berat atau biasa disebut hiperemesis gravidarum dengan gejala ibu muntah terus menerus tiap kali minum maupun makan, akibatnya tubuh ibu sangat lemah, muka pucat, dan frekuensi buang air kecil menurun drastis. Hal ini dapat menyebabkan cairan tubuh semakin berkurang dan darah menjadi kental (hemokonsentrasi) sehingga memperlambat peredaran darah. Dengan demikian konsumsi oksigen dan makanan ke jaringan juga ikut berkurang. Kekurangan makanan dan oksigen akan menimbulkan kerusakan jaringan yang dapat membahayakan kesehatan ibu dan perkembangan janin (Hidayati, 2009)

\section{Tingkat emesis gravidarum sesudahdiberikan aromaterapi lemon}

Mual muntah pada kehamilan sering disebut sebagai emesis gravidarum merupakan gejala yang umum terjadi pada trimester awal kehamilan.Keadaan ini dapat mengurangi kualitas hidup, mengganggu kemampuan wanita untuk berfungsi sehari-hari, dan secara negatif mempengaruhi hubungan dengan pasangan dan keluarganya. Karena kondisi demikian, seorang wanita hamil dapat mengalami tekanan atau stress. Hal ini disebabkan karena kurangnya pemahaman dan dukungan keluarga maupun orang terdekat, ketidakmampuan untuk makan dengan sehat, kesedihan karena kehilangan kehamilan normal, tidak ada pekerjaan, tekanan keuangan, isolasi, ketidakmampuan untuk merawat keluarga, keyakinan orang lain bahwa itu adalah psikosomatis dan anggapan masyarakat bahwa mual muntah tersebut adalah sesuatu yang wajar dalam kehamilan ('The Management of Nausea and Vomitting of Pregnancy and Hyperemesis Gravidarum', 2016).

Hasil penelitian menunjukkan bahwa gejala mual muntah berkorelasi secara negativedengan dukungan sosial dari lingkungan sekelilingnya. Ibu hamil dengan emesis gravidarum memerlukan adanya dukungan sosial sebagai tambahan dalam pengobatan. Cakupan dukungan harus diperluas mencakup keluarga, teman, dan profesional perawatan kesehatan('The Management of Nausea and Vomitting of Pregnancy and Hyperemesis Gravidarum', 2016). Sebagian besar masyarakat masih menggunakan terapi farmakologis dalam mengatasi keluhan tersebut, hal ini sesuai dengan hasil penelitian (Rofi'ah, Widatiningsih and Sukini, 2017). Menurut (Rinata and Ardillah, 2015) sebagian besar ibu hamil yang mengalami emesis gravidarum sudah tepat dalam mengkonsumsi obat-obatan anti mual namun masih belum tepat dalam melakukan pengobatan secara non farmakologis atau alamiah. Mual muntah dalam kehamilan sebenarnya dapat diatasi dengan cara non farmakologis misalnya dengan pengaturan pola makan, menghindari bau yang menyengat dan makanan berlemak, bersantan dan berminyak (Kundarti, Rahayu and Utami, 2015). Terapi komplementer juga dapat dilakukan untuk mengatasi emesis gravidarum, salah satunya dengan pemberian aromaterapi lemon. Penggunaan aromaterapi dalam mengatasi keluhan mual muntah ini dengan memanfaatkan aroma yang dihasilkan oleh minyak atsiri.

Negara kita adalah negara yang memiliki kekayaan alam berlimpah dan sebagai salah satu negara yang berpotensi sebagai penghasil minyak atsiri. Hal ini terbukti dengan banyaknya jenis tanaman, khususnya tanaman penghasil minyak atsiri di Indonesia. Salah satunya adalah tumbuhan yang mengandung minyak atsiri adalah lemon. Tumbuhan lemon sangat mudah tumbuh subur di lingkungan sekitar rumah. Sehingga, sangat tepat jika tumbuhan lemon ditanam sebagai tanaman obat keluarga disamping tanaman obat lainnya. Sumber minyak atsiri didapatkan dari bagian akar, batang, daun, bunga, dan buah dari berbagai tanaman tersebut. Minyak esensial ini dapat dijadikan sebagai produk aromaterapi yang memiliki banyak manfaat, diantaranya sebagai terapi komplementer, untuk merelaksasikan tubuh, bahan tambahan makanan, kosmetik, dan pengharum (Sofiani and Pratiwi, 2017).

Aromaterapi memberikan berbagai macam efek bagi penghirupnya, seperti ketenangan, kesegaran, bahkan dapat digunakan untuk membantu ibu hamil mengatasi mual. Aromaterapi dapat digunakan sebagai solusi untuk mengatasi mual muntah pada ibu hamil trimester pertama tanpa efek samping (Rahayu and Sugita, 2018). Pemakaian minyak essensial tumbuhan pada aromaterapi tidak dianggap benda asing di dalam tubuh, sehingga tidak memperberat kerja organ tubuh (Santi, 2013). Aromaterapi merupakan tindakan terapeutik dengan menggunakan minyak essensial yang bermanfaat untuk meningkatkan keadaan fisik dan psikologi sehingga menjadi lebih baik. Setiap minyak essensial memiliki efek farmakologis yang unik, seperti antibakteri, antivirus, diuretik, vasodilator, penenang, dan merangsang adrenal. Ketika minyak essensial dihirup, molekul masuk ke rongga hidung dan merangsang sistem limbik di otak. Sistem limbik adalah daerah yang memengaruhi emosi dan memori serta secara langsung terkait dengan 
adrenal, kelenjar hipofisis, hipotalamus, bagianbagian tubuh yang mengatur denyut jantung, tekanan darah, stess, memori, keseimbangan hormon, dan pernafasan (Runiari, 2010).

Aromaterapi lemon merupakan salah satu jenis minyak herbal yang sering digunakan dalam mengatasi mual muntah karena aman untuk masa kehamilan. Pada penelitian ini responden dibagi menjadi 3 kelompok dengan dosis pemberian aromaterapi yang berbeda. Pada kelompok pertama diberikan dosis $0.1 \mathrm{ml}$, kelompok kedua dosis $0.2 \mathrm{ml}$, dan kelompok ketiga dengan dosis $0.3 \mathrm{ml}$. Pemberian aromaterapi lemon dilakukan dengan cara responden menghirup tisu pada saat mengalami mual dan atau muntah selama 5 menit yang sudah diberikan \pm 5 tetes minyak essensial lemon sebanyak $0,1 \mathrm{ml} / 0,2 \mathrm{ml} / 0,3 \mathrm{ml}$ yang dicampur dengan $1 \mathrm{ml}$ air selama 12 jam.

Hasil penelitian menunjukkan bahwa pada masing-masing kelompok rata-rata skor mual muntah sebesar $5.29 ; 6.13$; dan 3.71. Jumlah responden dengan skor mual muntah diatas rata rata pada masing - masing kelompok sebanyak 5 orang; 7 orang dan 5 orang dari total keseluruhan sebanyak 46 orang responden. Menurut (Cheraghi and Valadi, 2010) aromaterapi lemon merupakan salah satu aromaterapi dengan kandungan utama Limonene yang dapat mengurangi rasa sakit (analgetik) termasuk rasa mual. Kandungan Linalil Asetat yang terdapat pada aromaterapi lemon merupakan senyawa ester yang terbentuk melalui penggabungan asam organik dan alkohol. Ester berguna untuk menormalkan keadaan emosi serta keadaan tubuh yang tidak seimbang serta memiliki khasiat sebagai penenang dan tonikum khususnya pada sistem syaraf(Wiryodigdo, 2008). Adanya kandungan zat-zat tersebut dapat dijadikan dasar bagi tenaga kesehatan khususnya bidan untuk memberikan asuhan kepada ibu hamil yang mengalami mual muntah untuk menggunakan terapi komplementer aromaterapi lemon untuk mengatasi keluhan yang dialami. Hal ini dapat menekan efek samping terapi farmakologis yang hingga saat ini masih sebagai terapi andalan dalam mengatasi emesis gravidarum.

\section{Efektivitas aromaterapi lemon dalam mengatasi emesis gravidarum}

Hasil analisa statistik pada penelitian ini menunjukkan bahwa tidak ada perbedaan ketiga kelompok dosis pemberian aromaterapi lemon dalam menurunkan tingkat emesis gravidarum. Meskipun demikian, pada analisa deskriptif dapat diketahui adanya perbedaan perubahan skor mual muntah pada masing-masing kelompok dosis yaitu 7 ; 17 ; 20. Pada kelompok pertama terdapat dua orang responden mengalami peningkatan skor mual muntah, pada kelompok tiga masih terdapat satu orang responden yang mengalami peningkatan, sedangkan pada kelompok kedua 3 orang responden tetap dan 12 orang responden mengalami penurunan. Untuk memperkuat analisa, hasil uji $\mathrm{t}$ test menunjukkan bahwa kelompok satu tidak ada perbedaan skor antara sebelum dengan sesudah intervensi; pada kelompok kedua dan ketiga terdapat perbedaan yang signifikan atara sebelum dengan sesudah intervensi. Berdasarkan analisa - analisa tersebut dapat dijelaskan bahwa dosis 0.2 dan 0.3 cukup efektif dalam mengatasi ememis gravidarum, meskipun secara bersamasama ketiga kelompok menunjukkan tidak ada perbedaan efektivitas dalam mengatasi emesis gravidarum.

Mual dan muntah selama kehamilan dapat disebabkan oleh perubahan dalam sistem endokrin yang terjadi selama kehamilan, terutama diseababkan oleh tingginya fluktuasi kadar hCG, khususnya karena periode mual atau muntah gestasional yang paling umum adalah pada 12-16 minggu pertama, sehingga hCG menjadi kadar tertingginya. disekresikan oleh sel-sel trofoblas blastosit. hCG dapat disekreksi dalam darah wanita dari sekitar tiga minggu gestasi (yaitu satu minggu setelah fertilisasi), dan peningkatan jumlah jaringan plasenta juga meningkatkan total jam terjadinya rasa mual di awal kehamilan. hCG bertanggung jawab terhadap penurunan TSH (thyroid stimulating hormone) yang banyak terjadi pada pada wanita yang mengalami hyperemesis gravidarum yang terbukti mengalami peningkatan fungsi tiroid, dengan sejumlah kecil mengalami tirotoksikosis gestasional dengan serum hCG melebihi $200 \mathrm{IU} / \mathrm{ml}$ (Tiran, 2009).

Berbagai penelitian sejalan dengan hasil penelitian ini, bahwa aromaterapi lemon khususnya dosis 0.2 dan 0.3 cukup efektif dalam mengatasi emesis gravidarum. Dosen atau tenaga pendidik sebagai transfer agent ofknowledge dapat menggunakan referensi dari berbagai hasil penelitian tentang manfaat aromaterapi lemon dalam mengatasi emesis gravidarum. Hasil penelitian (Afriyanti, 2018) menunjukkan terdapat perbedaan yang signifikan antara rata- rata frekuensi mual muntah sebelum dan setelah diberikan inhalasi aromaterapi lemon pada ibu hamil yang mengalami hiperemesis gravidarum dengan nilai $\mathrm{p}$ value $=0.0000$. Setelah pemberian inhalasi aromaterapi lemon responden menyatakan merasa lebih tenang dan nyaman serta sensasi mual 
yang dirasakan ibu tidak lagi seperti sebelum pemberian aromaterapi lemon. Setelah pemberian aromaterapi lemon responden juga menyatakan bahwa frekuensi mual muntah mulai berkurang, dimana ibu mengalami mual muntah terutama pada pagi hari tidak seperti biasanya dan pada waktuwaktu berikutnya yaitu siang dan malam hari frekuensi mual muntah yang dialami ibu sudah semakin sedikit, Kondisi ini mengindikasikan bahwa dengan pemberian inhalasi aromaterapi lemon dapat menurunkan frekuensi mual dan muntah pada ibu hamil yang mengalami hiperemesis gravidarum.

Hasil penelitian (Kia et al., 2014) juga sejalan dengan penelitian ini. Hasil penelitiannya menunjukkan $40 \%$ wanita telah menggunakan aroma lemon dalam meredakan keluhan mual dan muntah. Dari sekian tersebut 26,5 \% melaporkan bahwa aroma lemon merupakan cara yang efektif untuk mengontrol gejala mual muntah. Minyak essensial Lemon merupakan salah satu minyak herbal yang paling banyak digunakan dan aman bagi kehamilan. Penelitian (Astriana, Putri and Aprilia, 2015) menyarankan agar ibu hamil yang mengalami mual untuk menggunakan aromatherapi salah satunya lemon aromatherapi sebagai pilihan alternative untuk mengurangi mual pada kehamilan.

Penelitian lain yang juga menyatakan bahwa aromaterapi lemon efektif dalam mengurangi mual muntah dalam kehamilan adalah (Maternity, Ariska and Sari, 2017). Hasil penelitian tersebut menunjukkan bahwa ada pengaruh pemberian inhalasi lemon untuk mengurangi mual muntah pada ibu hamil trimester 1 di Bidan Praktek Swasta (BPS) Lia Maria Sukarame Bandar Lampung Tahun 2017 dengan $p$-value $=0.000$. Pada saat menghirup aromaterapi maka molekul yang mudah menguap akan membawa unsur aromatik yang terdapat dalam kandungan minyak tersebut ke puncak hidung. Rambut getar terdapat di dalamnya, yang berfungsi sebagai reseptor, akan menghantarkan pesan elektrokimia ke susunan saraf pusat. Pesan ini akan mengaktifkan pusat emosi dan daya ingat seseorang yang selanjutnya akan mengantarkan pesan balik keseluruh tubuh melalui sistem sirkulasi. Pesan yang diantar ke seluruh tubuh akan dikonversikan menjadi satu aksi dengan pelepasan substansi neuro kimia berupa perasaan senang, rileks, tenang, atau terangsang. Oleh karena itu, selain untuk mengatasi mual muntah ternyata aromaterapi lemon juga dapat digunakan untuk mengurangi nyeri haid (Suwanti, Wahyuningsih and Liliana, 2018), menurunkan tekanan darah (Kartika, 2015).
Secara umum aromaterapi dapat digunakan untuk mengobati berbagai penyakit epresi, gangguan pencernaan, sakit kepala, insomnia, nyeri otot, masalah perombakan, penyakit kulit, sendi bengkak, komplikasi terkait urin, dll(Ali et al., 2015). Pada penelitian selanjutnya, diharapkanpeneliti dapat mengembangkanpenelitian lain tentang penggunaan aromaterapi dalam mengatasi masalah yang berhubungan dengan keluhan lain pada masa kehamilan, persalinan, nifas dan sepanjang siklus kehidupan. Selain itu berbagai faktor yang mempengaruhi efektivitas maupun kinerja aromaterapi lemon perlu diperhatikan dalam upaya meningkatkan serta mengembangkan penelitian lebih lanjut.

\section{Simpulan}

Tingkat emesis gravidarum sebelum diberikan aromaterapi lemon pada rentang skor 3 23. Besar mean pada masing-masing kelompok adalah $8.41 ; 11.47$; dan 11.50 . Rentang skor pada masing-masing kelompok adalah $3-19 ; 4-21$; dan $4-23$. Tingkat emesis gravidarum sesudah diberikan aromaterapi lemon pada rentang skor 0 19. Besar mean pada masing-masing kelompok adalah $5.29 ; 6.13$; dan 3.71. Rentang skor pada masing-masing kelompok adalah $0-19 ; 0-14$; dan $0-9$. Tidak ada perbedaan efektivitas aromaterapi lemon diantara tiga kelompok dalam mengatasi emesis gravidarum, namun jika dianalisa pada masing-masing kelompok diperoleh hasil bahwa aromaterapi lemon dosis 0.2 dan 0.3 efektif dalam mengatasi emesis gravidarum.

Hasil penelitian ini bagi Perusahaan Obat Herbal dapat dijadikan salah satu wacana untuk menciptakan produk herbal khususnya aromaterapi lemon dengan dosis bervariatif dan harga terjangkau sebagai terapi untuk mengatasi mual muntah pada ibu hamil.

\section{Ucapan Terimakasih}

Terima kasih disampaikan kepada Poltekkes Kemenkes Semarang yang telah memberikan dana untuk penelitian ini. Ucapan terima kasih juga disampaikan kepada Kepala Puskesmas Mungkid serta Bidan yang telah membantu pelaksanaan penelitian.

\section{Daftar Pustaka}

Friyanti, D. (2018) 'Efektifitas Accupressure Pericardium dan Ihalasi Aromaterapi 
Lemon terhadap Frekuensi Mual dan Muntah pada Ibu Hamil dengan Hiper Emesis Gravidarum di Wilayah Kerja Puskesmas Tanjung Pati Kab 59 Kota Tahun 2018',Menara Ilmu, XII(8), pp. 3343.

Ahmad, J. (2013) Aneka Manfaat Ampuh Rimpang jahe Untuk Pengobatan. Yogyakarta: Dandra Pustaka Indonesia.

Ali, B. et al. (2015) 'Essential Oils Used in Aromatherapy: A Systemic Review', Asian Pacific Journal of Tropical Biomedicine. Elsevier (Singapore) Pte Ltd, 5(8), pp. 601611. doi: 10.1016/j.apjtb.2015.05.007.

Apriany, D. (2010) 'The Influence of Music Therapy Over Delayed Nausea Vomiting As Chemotherapy Effect On School Age Who Suffer Cancer At RSUP Dr. Hasan Sadikin Bandung',NANOPDF.com, pp. 56-69. Available at: https://nanopdf.com/queue/theinfluence-of-music-therapy-over-delayednausea-vomiting-as_pdf?queue_id=$1 \& \mathrm{x}=1541821262 \& \mathrm{z}=\mathrm{MzYuNzMuNzMuO}$ $\mathrm{Dg}=$

Astriana, Putri, R. D. and Aprilia, H. (2015) 'PENGARUH LEMON INHALASI AROMATHERAPY TERHADAP MUAL PADA KEHAMILAN DI BPS VARIA MEGA LESTARI S.ST.,M.Kes BATUPURU KECAMATAN NATAR KABUPATEN LAMPUNG SELATAN TAHUN 2015', Jurnal Kebidanan, 1(3), pp. 2011-2015. Available at: file:///C:/Users/USER/Downloads/29-92-1PB.pdf.

Cheraghi, J. and Valadi, A. (2010) 'Effects of antinociceptive and anti-inflammatory component of limonene in herbal drugs', Iranian Journal of Medicinal and Aromaterapic Plants, 26(3). Available at: https://www.cabdirect.org/cabdirect/abstract /20113020962.

Direktorat Jenderal Bina Gizi dan KIA Kemenkes RI (2011) Upaya Percepatan Penurunan Angka Kematian Ibu. Jaka: Kementrian Kesehatan Republik Indonesia.

Hidayati, R. (2009) Asuhan Keperawatan Pada Kehamilan Fisiologis dan Patologis. Jakarta: Salemba Medika.

Kartika, U. Y. (2015) 'Perbandingan Aromaterapi Lemon dan Aromaterapi Lavender terhadap Supplement.pdf.

Rahayu, R. and Sugita (2018) 'EFEKTIVITAS PEMBERIAN AROMATERAPI LAVENDER DAN JAHE TERHADAP
Perubahan Tekanan Darah pada Penderita Hipertensi di Wilayah Kerja UPK Puskesmas Klatulistiwa Pontianak', Jurnal PRONERS, 3(1). Available at: http://jurnal.untan.ac.id/index.php/jmkepera watanFK/article/view/26535.

Kia, P. Y. et al. (2014) 'The Effect of Lemon Inhalation Aromatherapy on Nausea and Vomiting of Pregnancy: A Double-Blinded, Randomized, Controlled Clinical Trial', Iranian Red Crescent Medical Journal, 16(3). Available at: https://www.ncbi.nlm.nih.gov/pmc/articles/P MC4005434/.

Kundarti, F. I., Rahayu, D. E. and Utami, R. (2015) 'Efektifitas Pemberian Serbuk Jahe (Zingiber Officinale) terhadap Tingkatan Mual Muntah pada Ibu Hamil', Jurnal Ilmu Kesehatan, 4(1), pp. 18-30. Available at: file:///C:/Users/USER/Downloads/document (1).pdf.

Maternity, D., Ariska, P. and Sari, D. Y. (2017) 'Inhalasi Lemon Mengurangi Mual Muntah pada Ibu Hamil Trimester Satu', Jurnal ilmiah Bidan, II(3), p. 619. doi: 10.1017/S0007123406000330.

Medforth, J. et al. (2013) Kebidanan Oxford dari Bidan untuk Bidan. Jakarta: EGC.

Munjiah, I. et al. (2015) 'Perbedaan Pengaruh Akupunktur dan Vitamin B6 terhadap Penurunan Intensitas Mual Muntah pada Emesis Gravidarum Berat', Indonesian Journal Of Education and Midwifery Care, 2(2), pp. 4-9. Available at: http://ijemc.unpad.ac.id/ijemc/article/view/1 $0 / 7$

Namazi, M. et al. (2014) 'Effects of Citrus Aurantium (Bitter Orange) on the Severity of First-Stage Labor Pain', Iranian Journal of Pharmaceutical Research, 13(3). Available at: https://www.ncbi.nlm.nih.gov/pmc/articles/P MC4177623/.

Niebyl, J. R. and Briggs, G. G. (2014) 'The Pharmacologic Management of Nausea and Vomitting of Pregnancy', Journal of Family Practice Women's Health Supplement, 63(2). Available at: http://www.nationalperinatal.org/Resources/ Nausea and Vomiting of Pregnancy_2_14 Journal of Family Practice Women's Health PENURUNAN FREKUENSI MUAL MUNTAH PADA IBU HAMIL TRIMESTER I DI BPM TRUCUK KLATEN', Jurnal Kebidanan dan 
Kesehatan Tradisional, 3(1), pp. 19-26. Available at: file:///C:/Users/USER/Downloads/371-7001-SM.pdf.

Rinata, E. and Ardillah, F. R. (2015) 'Penanganan Emesis Gravidarum Pada Ibu Hamil Di BPM Nunik Kustantina Tulangan-Sidoarjo', in Komunitas. Sidoarjo. Available at: http://eprints.umsida.ac.id/265/1/Prosiding_ Penanganan Emesis Gravidarum_universitasmuhammadiyahsido arjo.pdf.

Rofi'ah, S., Widatiningsih, S. and Sukini, T. (2017) Studi Fenomenologi Kejadian Hiperemesis Gravidarum pada Ibu Hamil Trimester I.

Runiari, N. (2010) Asuhan Keperawatan pada Klien dengan Hiperemesis Gravidarum Penerapan Konsep dan Teori Keperawatan. Jakarta: Salemba Medika.

Santi, D. R. (2013) 'Pengaruh Aromaterapi Blended Peppermint dan Ginger Oil terhadap Rasa Mual pada Ibu Hamil Trimester Satu di Puskesmas Rengel Kabupaten Tuban (The Effect of Peppermint and Ginger Blended Aromatherapy Oils on Nausea at the First Trimester Gravida in Puskesma', Sain Med, 5(2), pp. 52-55. Available at: https://www.kopertis7.go.id/uploadjurnal/D wi_Rukma_Santi_stikes_nu_tuban.pdf.

Sofiani, V. and Pratiwi, R. (2017) 'Review Artikel:
Pemanfaatan Minyak Atsiri pada Tanaman Sebagai Aromaterapi dalam SediaanSediaan Farmasi', Farmaka, 15(2), pp. 113. Available at: https://media.neliti.com/media/publications/ 227233-inhalasi-lemon-mengurangi-mualmuntah-pa-c458d0f0.pdf.

Suwanti, S., Wahyuningsih, M. and Liliana, A. (2018) 'Pengaruh Aromaterapi Lemon (Cytrus) terhadap Penurunan Nyeri Menstruasi pada Mahasiswi di Universitas Respati Yogyakarta', Jurnal Keperawatan Respati, 5(1), pp. 345-349. Available at: http://nursingjurnal.respati.ac.id/index.php/J KRY/index.

'The Management of Nausea and Vomitting of Pregnancy and Hyperemesis Gravidarum' (2016) in RCOG Green Top GuideLine. 69th edn. Royal College of Obstetrician and Gynaecologist, p. 10. Available at: ttps://www.rcog.org.uk/globalassets/docume nts/guidelines/green-top-guidelines/gtg69hyperemesis.pdf.

Tiran (2009) Mual Muntah Kehamilan Seri Asuhan Kebidanan. Jakarta: EGC.

Wiknjosastro, H. (2007) Ilmu Kebidanan. Jakarta: Bina Pustaka Sarwono Prawirohardjo.

Wiryodigdo, S. (2008) Kimia dan farmakologi Bahan Alami. Jakarta: EGC.

Wolfgang, S. and Michaela (2008) Aromatherapie. Vinna: Springer. 